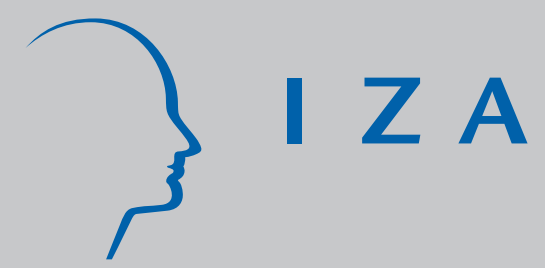

IZA DP No. 8228

Mr. Rossi, Mr. Hu and Politics: The Role of Immigration in Shaping Natives' Political Preferences

Guglielmo Barone

Alessio D'Ignazio

Guido de Blasio

Paolo Naticchioni

May 2014 


\title{
Mr. Rossi, Mr. Hu and Politics: The Role of Immigration in Shaping Natives' Political Preferences
}

\author{
Guglielmo Barone
}

Bank of Italy and RCEA

\author{
Alessio D'Ignazio \\ Bank of Italy
}

Guido de Blasio

Bank of Italy

Paolo Naticchioni

Roma Tre University and IZA

Discussion Paper No. 8228

May 2014

IZA

P.O. Box 7240

53072 Bonn

Germany

Phone: +49-228-3894-0

Fax: +49-228-3894-180

E-mail: iza@iza.org

\begin{abstract}
Any opinions expressed here are those of the author(s) and not those of IZA. Research published in this series may include views on policy, but the institute itself takes no institutional policy positions. The IZA research network is committed to the IZA Guiding Principles of Research Integrity.

The Institute for the Study of Labor (IZA) in Bonn is a local and virtual international research center and a place of communication between science, politics and business. IZA is an independent nonprofit organization supported by Deutsche Post Foundation. The center is associated with the University of Bonn and offers a stimulating research environment through its international network, workshops and conferences, data service, project support, research visits and doctoral program. IZA engages in (i) original and internationally competitive research in all fields of labor economics, (ii) development of policy concepts, and (iii) dissemination of research results and concepts to the interested public.
\end{abstract}

IZA Discussion Papers often represent preliminary work and are circulated to encourage discussion. Citation of such a paper should account for its provisional character. A revised version may be available directly from the author. 


\section{ABSTRACT}

\section{Mr. Rossi, Mr. Hu and Politics: The Role of Immigration in Shaping Natives' Political Preferences}

We analyze the impact of immigration on voting. Using Italian municipality data and IV estimation strategy, we find that immigration generates a sizable causal increase in votes for the centre-right coalition, which has a political platform less favorable to immigrants. Additional findings are: big cities behave differently, with no impact of immigration on electoral outcomes; gains in votes for the centre-right coalition correspond to loss of votes for the centre-left parties, a decrease in voter turnout, and a rise in protest votes; cultural diversity, competition in the labor market and for public services are the most relevant channels at work.

JEL Classification: D72, P16, J61

Keywords: immigration, voting, political economy

Corresponding author:

Paolo Naticchioni

Roma Tre University

Faculty of Economics

Via Silvio D'Amico 77

00154 Rome

Italy

E-mail:p.naticchioni@gmail.com

\footnotetext{
* We thank Olivier Bargain, Francesca Carta, Carlotta Berti Ceroni, Francesco D'Amuri, Sauro Mocetti, Henri Overman, Matthew Wakefield, and participants in the Italian Association of Labour Economists (AIEL), the Association of Italian Economists (SIE), the Brucchi-Luchino 2013, and the seminar held in GREQAM (Marseille), Luiss (Rome), Bologna and Bank of Italy (Rome). The views expressed in the paper are those of the authors and do not necessarily reflect those of the institutions they are affiliated with.
} 


\section{NON-TECHNICAL SUMMARY}

International migration is a global phenomenon, widely investigated in the literature. An important but less investigated issue concerns the role of immigration for the political preferences of the natives, who often have strong views and prejudices on the issue. These feelings are likely to be among the determinants of residents' political choices at the polls. At the European institutional level the issue is even more important, since immigration policy is at the core of the debate on the future of the European Union. Interestingly, parties that are against the Euro area and that are proposing an exit strategy for their countries are often associated with protectionist views on immigration. The Front National in France, the Dutch Freedom Party and the Italian Lega Nord (Northern League) offer some examples of these combined political positions.

This paper analyzes the role of immigration in shaping electoral outcomes in the case of Italy, where immigration increased rapidly in the last two decades. As reported by an Italian newspaper, of the first ten family names entered at the register office of Milan in 2012, three were originally from China, the second most recorded being the Chinese Hu. The most frequently recorded name remains Rossi, a typical Italian surname. Twenty-five years ago no foreign last name (among the first ten) was recorded at the same office.

The paper investigates the impact of immigrants on the political choices of natives at the national political elections by comparing the voting pattern in about 8,000 municipalities differently exposed to migration flows, in parliamentary national elections of 2001, 2006, and 2008. Two of them (2001 and 2008) were won by the centre-right coalition, headed by Mr. Silvio Berlusconi. The election of 2006 was, instead, won by the centre-left coalition, headed by Mr. Romano Prodi. With respect to immigration, the political platforms of the two coalitions were, consistently over the three elections, very different. In short, the centre-left alliance had a more open stance, stressing the importance of the immigrants for the prospects of the domestic economy, the duty of solidarity for a high-income country, and the benefits of a multi-ethnic society. On the other hand, the political program of the centre-right coalition had a less liberal stance: the emphasis was more on the social problems (e.g. crime and lack of jobs) related to immigration and the threat that people with different backgrounds could pose for the domestic way of life.

The paper finds that a $1 \%$ increase in the share of immigrants in a municipality entails a $1.26 \%$ increase in the share of voting going to the centre-right coalition headed by Mr. Berlusconi. Additional findings are: big cities behave differently, with no impact of immigration on electoral outcomes; gains in votes for the centre-right coalition correspond to loss of votes for the centre-left parties, a decrease in voter turnout, and a rise in protest votes; cultural diversity, competition in the labor market and for public services are the most relevant channels at work. 


\section{Introduction}

International migration is a global phenomenon. According to the United Nations, in 2013 there were 136 million international migrants in developed countries with a sizeable increase between 2000 and 2010 (UN, 2013). The effects of immigration for the receiving countries have been extensively investigated. The literature has focused mainly on labor market aspects (see for instance Friedberg and Hunt, 1995, Card, 2001, Ottaviano and Peri, 2008), the cultural environment (Ottaviano and Peri, 2006), the crime rate (Moehling and Piehl, 2007, Bianchi et al, 2012), and the attitudes of natives (Card et al., 2012, Mayda, 2006). An important but less investigated issue concerns the role of immigration for the political preferences of the natives, who often have strong views and prejudices on the issue. These feelings are likely to be among the determinants of residents' political choices at the polls. At the European institutional level the issue is even more important, since immigration policy is at the core of the debate on the future of the European Union. Interestingly, parties that are against the Euro area and that are proposing an exit strategy for their countries are often associated with protectionist views on immigration. The Front National in France, the Dutch Freedom Party, the United Kingdom Independence Party in the UK, and the Italian Lega Nord (Northern League) offer some examples of these combined political positions. Marine Le Pen, leader of the Front National which achieved a surprising 26\% of votes cast in the European Election in France in May 2014, proposed in February 2014 a referendum for stricter immigration regulation and in May 2014 a referendum on whether France should remain within the European Union, offering yet further confirmation that the impact of immigration on electoral outcomes is going to be a crucial issue in Europe in the near future.

This paper analyzes the role of immigration in shaping electoral outcomes in the case of Italy, which - we argue - is particularly interesting for two reasons above all. First, immigration has been a recent and rapidly growing phenomenon, which means that the power of the empirical test we carry out is very high. In 1998 the share of immigrants over natives, according to the Eurostat data, was as low as $1.7 \%$ (compared with 9\% in Germany, $5.6 \%$ in France). Since 1998, however, the country has seen ample inflows, reaching 8\% in 2012, while in Germany and France, for instance, the shares of immigrants has remained fairly constant. As reported by a national newspaper, ${ }^{1}$ of the first ten family names entered at the register office of Milan in 2012, three were originally from China, the second most recorded being the Chinese $\mathrm{Hu}$. The most frequently recorded name remains Rossi, a typical Italian surname. Twenty-five years ago no foreign last name (among the first ten) was recorded at the same office. Second, in the last 20 years the Italian political scene has been dominated by Mr. Silvio Berlusconi and his centre-right coalition: this has given rise to a widespread international debate on the 'anomaly' in Italian politics, given Mr. Berlusconi's media control (Durante and Knight, 2012) and his ambiguous adherence to the rule of law (Ginsborg, 2005; Lane, 2005; The Economist²).

We focus on the parliamentary national elections of 2001, 2006, and 2008. Two of them (2001 and 2008) were won by the centre-right coalition, headed by Mr. Silvio Berlusconi. The election

\footnotetext{
${ }^{1}$ See: http://milano.repubblica.it/cronaca/2012/04/15/news/fra _ _cognomi_pi_diffusi_a milano il_cinese hu_scalza_sciur_brambilla$33351789 /$

2 http://www.economist.com/topics/silvio-berlusconi.
} 
of 2006 was, instead, won by the centre-left coalition, headed by Mr. Romano Prodi. With respect to immigration, the political platforms of the two coalitions were, consistently over the three elections, very different. In short, the centre-left alliance had a more open stance, stressing the importance of the immigrants for the prospects of the domestic economy, the duty of solidarity for a high-income country, and the benefits of a multi-ethnic society. On the other hand, the political program of the centre-right coalition had a less liberal stance: the emphasis was more on the social problems (e.g. crime and lack of jobs) related to immigration and the threat that people with different backgrounds could pose for the domestic way of life. Moreover, in all the elections the centre-right coalition included the Lega Nord party, which has taken on the role of a nationalistic party opposed to immigration (Passarelli, 2013), and Alleanza Nazionale, the more moderate successor of the Movimento Sociale Italiano (MSI), the neo-fascist party in post-WWII Italy.

We investigate the impact of immigrants on the political choices of natives at the national political elections by comparing the voting pattern in about 8,000 municipalities differently exposed to migration flows. Focusing on small territorial units delivers substantial benefits in the empirical strategy, as attitudes to migration depend mainly on the proximity between natives and immigrants, for instance because there could be competition for the public services provided locally and for jobs in the local labor market. To deal with endogeneity issues we use the well-known instrument proposed by Card (2001), which exploits the fact that immigrants tend to move to an area where a group of immigrants of the same ethnicity is already present. The identifying assumption is that local economic shocks that attracted immigrants in the past (in 1991) are uncorrelated with current political preferences, conditional on the full set of controls. We claim that this instrument is extremely convincing for our empirical application, because of the sharp discontinuity that occurred in Italian politics after the so-called 'Mani Pulite' scandal (1992-1994). One of its effects was the disappearance of the Democrazia Cristiana and the Partito Socialista, the two main parties that governed the country in the previous decades. Two issues are crucial for our analysis. First, the two parties that disappeared in 1992-94 did not have any specific stance against immigration, which was still a minor phenomenon at that time. Second, new parties joined the political arena after 1992-1994. Silvio Berlusconi's party was founded in January 1994. Further, the two main parties included in the centre-right coalition with a more explicit anti-immigration stance (Lega Nord and Alleanza Nazionale) started participating in the Italian national elections after 1991, the year used to derive our instrument. This ensures that the location choices of the first wave of immigrants in 1991 were not affected by the political local strength of the Silvio Berlusconi's coalition and of related parties.

Our results are as follows. In our preferred specification, i.e. controlling for endogeneity and municipality unobserved heterogeneity, we find that a $1 \%$ increase in the share of immigrants in a municipality entails a $1.26 \%$ increase in the share of voting going to the centre-right coalition. As original additional finding, we find no impact for big cities, suggesting that they behave differently. We discuss the explanations underlying this interesting finding. 
We also carry out two main robustness checks. The first lies in use of the local labor market data, instead of municipality data, in order to reduce possible spillover effects due to the fact that immigration flows in a single municipality might also affect the surrounding municipalities, through the mobility decisions of natives. The second robustness check regards the change in the national electoral system in 2005 that applied to elections in 2006 and 2008, as in principle the impact of immigration on electoral outcomes might be affected by how votes are translated into seats. In both cases, we find that our main results remain basically unaffected.

We also show that the gain in votes for the centre-right coalition is associated with a loss of votes for all the other coalitions of center and left, with the greatest fall for the main center-left coalition headed by Romano Prodi in 2006. Furthermore, to the best of our knowledge this paper is the first to highlight that the increase in immigration causes a decrease in voter turnout, even if not statistically significant, and a rise in protest votes, i.e. blank and invalid ballot papers. The latter finding suggests that the recent trends in immigration have contributed to a surge of disaffection towards political participation.

The final contribution of the paper concerns the channels along which the impact of immigration on votes for the centre-right coalition occurs. Using interaction terms, as well as microdata descriptive evidence, we show that cultural diversity, competition in the labor market and competition for public services all play an important and statistically significant role, while the native perception that immigrants are responsible for a rising crime rate has a positive but not statistically significant impact.

Compared to the existing literature (see Section 2), the novelty of our paper lies in the following main aspects. First, we study the Italian case that we argue is very relevant, both in terms of data variability (i.e. political heterogeneity and immigration inflows) and political importance. Second, the 'Mani Pulite' political scandal in 1992-94 provides high power to our natural experiment-like exercise, using an instrument variable approach. Third, we investigate the impact of immigration on additional unexplored outcomes such as turnout and protest votes. Fourth, we point out that big cities behave differently, and we discuss the related explanation. Fifth, we include an extensive analysis of the channels behind the impact of immigration, using both municipality data and suggestive microdata evidence.

The paper is structured as follows. Section 2 briefly summarizes the scant literature on the subject. Section 3 illustrates for Italy the trends in immigration and how it is regulated, together with the political platforms of the two main coalitions. Section 4 introduces the data while section 5 focuses on the empirical strategy. In section 6 we present our baseline results, also highlighting the peculiar role of big cities, and the robustness checks. Section 7 provides evidence on some potential channels along which the effect of immigration on voting patterns percolates, using both Itanes microdata and municipality data. Section 8 concludes. 


\section{Related literature}

The literature on the impact of immigration on electoral outcomes is very recent and rather scant.

Mendez and Cutillas (2014) investigate whether the immigration to Spain affected the outcome of the presidential elections held in the 1996-2011 period, when the immigrant share rose sharply. They use 48 provinces observed in five election year as units of analysis. Using province-level fixed effects and instrumental variable analysis (following Card, 2001) they find that immigration inflow has no robust effect on support for anti-immigration coalitions. When they split the immigrant incidence according to nationality, a positive impact on antiimmigration coalitions emerges when African immigration is considered.

Another very recent contribution is Otto and Steinhardt (2014), who analyze the impact of immigration inflows in 103 districts in the city of Hamburg in the 1987-1998 period. Their OLS fixed-effects estimates document that a one percentage-point increase in the share of immigrants entails a 0.225 percentage-point increase in the share of extreme right-wing parties in both federal state and national elections (and a corresponding decrease for the left-wing Green party). In a robustness check, these findings are qualitatively confirmed when they instrument the current share of immigrants with its 10-year lagged value.

Two additional (so far unpublished) papers deal with the impact of immigration on the political preferences of the natives. Halla et al. (2013) analyze whether immigration dynamics positively affect the votes for the Freedom Party of Austria (FPO), a party with a clear antiimmigration stance. They make use of historical settlement patterns of immigrants as a source of exogenous variation for the recent spatial distribution of immigrants (Card, 2001). Their baseline 2SLS-estimate suggests that a one-percentage-point increase in the share of immigrants in a municipality increases the percentage of FPO votes in general elections by about 0.35 percentage points. Their analysis is mainly in cross-section, exploiting a pooled sample of six national elections at the municipality levels (from 1979 to 2002), using a time invariant instrument. They also investigate some heterogeneity in the impact, according for instance to the skill level of natives and immigrants, and to the share of immigrant children.

Gerdes and Wadensjo (2010) investigate how the influx of refugees has affected votes for the main political parties at the municipality levels in Denmark. Their analysis covers a period that includes four local government elections and four general elections between 1989 and 2001. According to their OLS and fixed-effects estimates, the shares of refugees are positively associated with the two main anti-immigration parties while mixed evidence is detected for other political parties: for instance they show that even a party with a pro-immigration stance, the Socialist People's Party, gains from immigration, while the Liberal party, more to the centre, loses.

Another interesting and related paper is Mayda (2006), which analyzes economic and noneconomic determinants of individual attitudes toward immigrants, within and across countries. This paper finds that opinions about immigration policy are significantly correlated with individual skill in the host country. Skilled individuals are more (less) likely to be proimmigration in countries where the relative skill composition of natives to immigrants is high 
(low). Mayda (2006) also shows that individual skill is positively correlated with proimmigration preferences in countries with high per capita GDP, and negatively correlated with pro-immigration preferences in those with low per capita GDP. Facchini and Mayda (2009) investigate similar research issues with specific focus on welfare policies. Another related paper is Card et al. (2012), which investigates the impact of immigration on the changes in composition of the local population, threatening the compositional amenities that natives derive from their neighborhoods, schools, and workplaces. They find that compositional concerns are 2-5 times more important than concerns over wages and taxes in accounting for individual attitudes towards immigration.

\section{Immigration trends, regulations and political platforms in Italy}

\subsection{Immigration trends in Italy}

Immigration is a phenomenon of growing importance in many countries, and particularly in Europe. According to Eurostat (2013), at the end of 2011 in the EU-27 resident immigrants amounted to about $4.1 \%$ of the population (20.7 million). In Italy, the share of resident immigrants had reached 8.1\% (4,8 million) in 2012, slightly below that of Germany and above that of France (see Figure 1).

\section{[Figure 1]}

Unlike other large European economies, Italy has experienced immigration as a recent phenomenon. In 1998 the share of immigrants over Italian natives, according to the Eurostat data, was still as low as 1.7\%; it was 9\% in Germany and 5.6\% in France. Starting from 1998, the country experienced sizeable inflows, reaching $8 \%$ in 2012, while in Germany and France the shares of immigrants have remained fairly constant. Figure 2 documents the striking increase in immigrations in Italy from 1998 to 2010.

[Figure 2]

\subsection{Immigration regulations and political platforms in Italy}

This Section documents that the two main political coalitions that competed to run the country in 2001, 2006 and 2008 had two very different platforms with regard to immigration. The two different standpoints remained unchanged over the decade.

The anti-immigration stance of the Berlusconi coalition has been one of the recurrent issues in the election campaign, due also to the presence in the coalition, apart from the Berlusconi's party Forza Italia, of both Alleanza Nazionale (National Alliance), headed by Gianfranco Fini, the successor to the neo-fascist party in post-WWII Italy (Movimento Sociale Italiano - MSI Italian Social Movement), and Lega Nord, headed by Umberto Bossi, which has also taken the 
role of a nationalistic party against immigration. The election posters illustrated in Figure 3, which refers to the campaign of Mr. Fini, seems quite evocative: the sentence highlighted in yellow says: "never again illegal immigrants around the corner." The election posters of the Lega Nord, reproduced in Figure 4, seem to be even more unambiguous (the poster on the LHS says "We stopped the invasion"; the one on the RHS says "Protect your future: get rid of illegal immigrants").

On the other hand, the centre-left coalition had a more open stance with respect to immigration. First, this coalition underscored the importance of immigrants for the prospects of the domestic economy. Second, harking back to the tradition of internationalism of the leftist parties (and that of hospitality of the Catholic parties belonging to the centre-left alliance), the importance was highlighted of the duty of a high-income country to show solidarity. Finally, on a more cultural level, the leading spokespersons of the centre-left coalition frequently presaged the benefits of a multi-ethnic society.

\section{[Figure 3]}

[Figure 4]

The diverging electoral platforms corresponded to very different legislative and administrative activities of the two coalitions, once in power. In 1998, the centre-left government headed by Romano Prodi issued Law 40/98 (the so-called 'Turco-Napolitano law'), which was an attempt to regularize the position of non-EU immigrants and improve their integration, introducing regulations in the areas of employment, health and education. The three main goals of the Turco-Napolitano were to implement more effective planning to deal with persons entering for employment reasons, preventing illegal immigration, and integrating foreign citizens who had legal residence permits. The Turco-Napolitano was considered a liberal, and even pro-immigrant, law, compared with some closed-door policies of other European countries at that time.

In 2001, the centre-right coalition had no sooner won the election than it passed Law No. 189/2002, known as the 'Bossi-Fini law', Bossi and Fini being the leaders of the two parties with more accentuated anti-immigration stances within the coalition. This law amended the 1998 immigration law and introduced some new stringent clauses. According to the Bossi-Fini law, every year the Prime Minister has to lay down the number of non-EU workers who can be admitted in the country in the following calendar year. The law states that in order to apply for a residence permit, an immigrant needs a 'residence contract' ('contratto di soggiorno') - i.e. a contract of dependent employment. When the contract expires, the immigrant worker must either renew it or return to the country of origin. Residence permits issued for employment reasons can last for a maximum of two years, even if the worker has an open-ended employment contract. ${ }^{3}$ After six years of regular residence in Italy, non-EU citizens will be able

\footnotetext{
3 The new law also states that only non-EU immigrants with a regular residence permit can be entitled to request family reunification.
} 
to apply for a form of permanent permit. Furthermore, with this law Italy has been one of the first European countries to require immigrants applying for residence permits to provide their fingerprints, an issue with very important symbolic content. Another important difference with the Turco-Napolitano is that, in the case of deportation, it will be immediate and will not be suspended even if the immigrant appeals to the courts (as stated by the 1998 law). Further, if illegal immigrants return to Italy, they will be arrested and tried by the courts. ${ }^{4}$

Differences between coalitions in political platforms and attitudes against immigrants are borne out when the "Fondazione Rodolfo De Benedetti" index of strictness of migration policies is taken into account. Table 1 compares this index for a number of EU countries over the 1994-2006 period (and its legend includes details for the computation of the index). Italy scores high in the ranking, even though the level of its anti-immigration policy features seems to be quite in line with other European countries (except France). More interestingly for our purpose, the value of the index during the years (1996-2001) in which the centre-left coalition was in office (Figure 5) is appreciably lower than those referring to the two periods (1994-96 and 2001-06) in which there was a centre-right government.

\section{[Table 1]}

[Figure 5]

Finally, the number of expulsion orders can be taken as an additional proxy for the effectiveness and enforcement of the immigration policies of the two coalitions. Over the period 1998-2008, for which we have data, the Italian judiciary prescribed over 300,000 expulsions. Splitting the time-span according the type of ruling coalition, we find that under a centre-left government on average just over 20,000 immigrants per year were forced to abandon the country. Under a centre-right government this figure rose to just over 35,000.

\section{Data}

We use a panel of all Italian municipalities for which we observe the outcomes of national political elections that took place in 2001, 2006 and 2008, the immigration share, as well as other relevant demographic and economic features.

Data on election outcomes are drawn from the dataset 'Atlante storico elettorale Zanichelli' (Corbetta and Piretti, 2009), providing for each municipality detailed information on votes for all parties in the political elections that took place over the 2000s. Political parties were grouped

\footnotetext{
4 The anti-immigration stance of the centre-right coalition can also be detected from public statements. For instance, in 2007 the would-be Prime Minister Silvio Berlusconi threatened to ban Romanian workers from Italy (The International Herald Tribune, November 4, 2007) and then, once in power, called for the expulsion of groups of migrants (The Economist, January 29, 2009), which earned the Italian government a reprimand from the EU.
} 
according to their political platforms (right, centre-right, centre, centre-left, left) and the share of votes was then computed. 5

With regard to immigration, we exploit a detailed dataset maintained by the National Institute of Statistics (Istat), providing for each of the 8,000 Italian municipalities the number of foreign born residents on January, 1 , from $2002 .{ }^{6}$ As for control variables, the time-variant variables used in our baseline OLS specification were drawn from Istat Territorial Statistics while the time-invariant covariates come from the Istat Census held in 2001 (Istat, 2001).

Data on immigrants by municipality and country of origin in 1991, which we use to construct our instrumental variable, have been estimated combining information on immigrants by municipality and area of the world (provided by Istat) and data on residence permits by province and country of origin (provided by the Italian Ministry of the Interior). Basically, we estimate data by municipality and nationality by imputing for each municipality within a given area of the world the nationality share observed at the provincial level.

\section{Empirical strategy}

The institutional setting allows us to focus our analysis on natives, since immigrants cannot vote in National political elections. Further, since immigration was very low until the nineties and since it takes a long time applying for and receiving Italian citizenship, we can disregard the issue of naturalization, which is still a very recent and negligible phenomenon in Italy.

Another advantage of focusing on a national voting context is that the political platforms of the two competing coalitions with respect to immigration are clearly identifiable. Moreover, they do not reflect local circumstances, as might be the case with local elections. Finally, electoral regulation at the nation-wide level is the same all over the country.

We estimate the following regression model:

$$
y_{m t}=\beta_{0}+\beta_{1} I M M_{m t}+X_{a t}^{\prime} \beta_{2}+\lambda_{m}+\mu_{t}+\varepsilon_{m t}
$$

where the dependent variable $y_{m t}$ is the share of valid votes for the centre-right alliance, ${ }^{7}$ defined at the municipality level $m$ for each of the three elections $(t=2001,2006,2008) .{ }^{8}$ Our

\footnotetext{
${ }^{5}$ See Appendix 1 for detailed definitions of the coalitions. Note that there is a residual coalition, called in the appendix as 'cross parties coalition', which is composed of a mix of very small parties that cannot easily be attributed to the other coalitions. This residual coalition accounts for less than $1 \%$ in terms of votes at the national elections. We gave it no further consideration in the following pages.

${ }^{6}$ Note that since these data start in 2002, we use the 2002 wave (computed on January, 1st) for the 2001 election.

7 The extreme right parties are included in the centre-right coalition; these parties, however, are negligible in terms of votes. Our results do not change when excluding the extreme right parties, as shown in table 7.

8 In 2001 there was a mixed electoral system (25\% of members under a proportional system and $75 \%$ under a majoritarian system). We consider as dependent variable the coalition vote shares under the proportional system. In 2006 and 2008 elections the system becomes basically proportional with a winning bonus, and hence our dependent variable is the coalition share.
} 
variable of interest is $I M M_{m t}=\left(\frac{\text { Immigrants }}{\text { Population }}\right)$, i.e., the share of immigrants over population in the municipality. $\lambda_{m}$ is a set of municipality fixed effects that controls for any time-invariant unobserved variable, while year dummies $\mu_{t}$ control for changes in political preferences at the national level; $\varepsilon_{m t}$ represents the regression error. $X_{a t}$ is a set of variables aimed at capturing observable economic and social differences across municipalities. It includes time variant covariates: population to capture demographic dynamics; population density to capture nonlinear urban effects; yearly GDP growth rate at regional (NUTS-2) level to take into account local business cycles that may simultaneously affect both immigrant settlement and political preferences. Note also that in the specifications without municipality fixed effects we use the following time-invariant covariates computed in 2001, to control for additional observed differences across municipalities: a proxy for social capital (the share of blood donors at municipality level); the aging index (ratio between population over 65 and population below 15); the share of graduates; the employment rate. Table 2 provides the descriptive statistics for all variables.

[Table 2]

Observations are weighted by the log of municipality voters (those who have the right to vote). This choice balances out two competing needs: (i) giving larger weight to larger municipalities and (ii) not making results entirely driven by very few municipalities, given the high positive skewness of the distribution of population across Italian municipalities. In Section 6.2 we tackle the issues related to the role of the size of a city for our findings. Finally, standard errors are clustered at the municipality level.

The OLS estimates, even when including municipality fixed effects, cannot be taken in a causal way. They might be flawed by the usual drawbacks. First, an omitted variable bias may be at work. For instance, an unobserved positive productivity shock affecting firms located in the municipality could lead to an increase of both labor demand for immigrants and political preferences for the centre-right alliance, to the extent that the latter better serves the needs of the rich. This would entail an upward bias. Second, our results might reflect reverse causation, as the immigrants could avoid places where a large proportion of people averse to multiculturalism live. This would imply a downward bias. Finally, there could also be measurement error in the independent variable, as the tracking of the non-natives over the national territory is admittedly imperfect, both because of illegal immigrants and because those who leave a municipality may omit to signal their departure. Also in this case the estimates would be biased downward.

To address all these issues, we adopt an instrumental variable approach. Following Card (2001), we exploit the fact that immigrants tend to move to areas where a group of immigrants with the same ethnicity has already settled in the past. The identifying assumption is that local economic shocks that attracted immigrants in the past are uncorrelated with present political 
preferences conditional on the full set of controls included in the equation (1). In detail, we construct our instrument as:

$$
\frac{\sum_{c=1}^{N} \delta_{m c} \text { Immigrants }_{c t}}{\text { Population }_{m t}}
$$

where $\delta_{\mathrm{mc}}$ is the share of immigrants from country $c$ in municipality $m$ in 1991, Immigrants st $_{\text {is }}$ the country-level number of immigrants from country $c$ in year $t(t=2001,2006,2008)$, Population $_{m t}$ is the total population in municipality $m$ and year $t$, and $N$ stands for the number of top foreign nationality in the host country in $1991 .{ }^{9}$

As pointed out in the introduction, we claim this instrument is particularly convincing for our empirical analysis because of the breakdown that occurred in Italian politics in 1992-1994, the so called 'Mani Pulite' scandal. One of the effects of this scandal was the disappearance of the Democrazia Cristiana, the main party that had headed the country since the end of WWII, and of the Partito Socialista, which played a very important role in supporting Democrazia Cristiana in the eighties. It is worth noting that these two parties that disappeared in 1992-94 did not have any specific stance against immigration, which was at that time still a minor phenomenon. Even more important for our empirical approach, new parties joined the political arena after 1992-1994. Silvio Berlusconi's party (Forza Italia) was founded in January 1994. Further, the two main parties included in the centre-right coalition with anti-immigration stances (Lega Nord and Alleanza Nazionale) started participating in Italian national elections after 1991, the year used to derive our instrument. The Lega Nord participated for the first time in 1992, Alleanza Nazionale in $1994 .{ }^{10}$ This ensures that the location choices of the first wave of immigrants in 1991 were not affected by the political local strength of Silvio Berlusconi's coalition and related parties.

\section{The econometric results}

\subsection{Baseline Results}

Table 3 displays the baseline estimates. In column (1) we start by showing the OLS results, with specification without municipality fixed effects which in any case includes both the timevariant and time-invariant controls described above, and year dummies. Since our dataset is a panel of roughly 8,000 municipalities observed over the three election years $(2001,2006,2008)$, OLS estimates in column (1) exploit both cross-section and time variability. Estimates suggest a positive (and statistically significant) correlation between the share of immigrants and the percentage voting for the centre-right coalition. The magnitude of the effect is not negligible: a $1 \%$ increase in the share of immigrants is associated with an increase of $0.389 \%$ at the polls. In

\footnotetext{
${ }^{9}$ We set $N$ equal to 15: Albania, Romania, Morocco, China, Philippines, Tunisia, Serbia and Montenegro, Macedonia, Poland, India, Peru, Senegal, Egypt, Sri Lanka, Ecuador. The share of these nationalities in 1991 amounted to around $60 \%$ of total immigration.

${ }^{10}$ Alleanza Nazionale was founded in January 1994. With respect to the pre-existing party, the former fascist party Movimento Sociale Italiano, Alleanza Nazionale had the main goal to enter a centre-right government, while the Movimento Sociale had very little political importance before 1994 since it had always been an opposition party.
} 
column (2) we introduce municipality fixed effects, in order to deal with unobserved municipality heterogeneity (dropping the time-invariant covariates from the specification). The estimated coefficient falls slightly (0.284) while remaining highly significant.

[Table 3]

Column (3) documents the result derived using the IV estimator with municipality fixed effects. The impact of local immigration on the share of preferences for the centre-right coalition is now much larger and highly significant, suggesting a substantial overall downward bias in the FE estimates. This finding highlights the fact that among the sources of bias those delivering attenuation, such as measurement error and/or reverse causality, are likely to play a major role. The size of the estimated effect is large: an increase in $1 \%$ of the immigrant shares entails an increase in votes for the center-right party of 1.26 percentage point; put differently, a one-standard deviation increase in IMM entails an increase in the dependent variable amounting to about $1 / 3$ of its standard deviation. Note that the instrument fits well the actual distribution of immigrants across Italy's municipalities: the first stage coefficient has the expected sign, it is equal to 0.08 and it is highly significant (t-stat equals to 5.3). Furthermore, the F-statistic is above 10, meaning that our estimates do not suffer from the issue of a weak instrument. From now on, the specification of column (3) is taken to be our preferred specification, since it allows for control for both unobserved municipality heterogeneity and endogeneity.

It is also interesting to compare the magnitude of impact reported in this paper for Italy with the findings in other papers in the literature. Actually, the only comparable paper is Halla et al (2013) which uses comparable data and methodology. It emerges that the coefficient for Italy is higher than for Austria. This may well be due to the fact that while in Italy the dependent variable refers to a leading coalition, with shares at elections around $40-50 \%$ of valid votes, for Austria the 'Freedom Party of Austria' has been able to capture much lower shares, even lower than half those of the centre-right in Italy. In such a perspective, the differences in the two impacts (0.4 as against 1.26) are less striking. Furthermore, differences in coefficients could be related to the fact that immigration is a much more recent phenomenon in Italy. ${ }^{11}$

\subsection{An interesting finding: the role of big cities}

Our findings do not hold for big cities. In Table 4, columns (1), (2) we replicate the specifications of Table 3 weighting the observations by voters instead of log voters. This amounts to leaving the very few large municipalities to account largely for the results. The

\footnotetext{
${ }^{11}$ Another related issue lies in the possibility to test whether, according to our results, immigration has been a crucial factor in determining the electoral victories of the centre-right coalitions (2001 and 2008) or the reduced margin of victory for the centre-left alliance in 2006. Unfortunately, our findings hardly serve this purpose, since we use an IV approach. The advantage of this approach is that it is possible to derive a causal impact of immigration on electoral outcomes. The disadvantage is that the impact is identified on the group of compliers, and not on the whole population (Deaton, 2010).
} 
estimated effects decrease drastically. The fixed effects estimates are lower than those in Table 3, and when using IV the coefficient comes very close to zero (and even negative) and is no longer statistically significant. On the other hand, our results are fully confirmed when using the number of voters as weights but trimming the sample at the 99th percentile of the municipality distribution of voters (Table 4, columns (3), (4)): the estimates in fixed effects and in IV are very close to those in Table 3. This evidence suggests that big cities behave differently, i.e. there is no impact of immigration on votes for the centre-right coalition. ${ }^{12}$ This is confirmed when using in the estimates only big cities, i.e., the last percentile. Column (5) and (6) shows that estimates are close to zero and not statistically significant, and in IV the point estimate is even negative.

To explain why big cities behave differently, we propose three tentative and (possibly) complementary explanations. First, in big cities it is easier to have segmented neighbourhoods, i.e., natives and immigrants might be located at a certain distance from each other. Therefore, natives may have a lower perception of some possible negative sides of immigrations (such as crime, competition for local public services, etc.), while however having the opportunity to exploit the positive sides of immigration (such as cheap housemaids and nannies, etc.). A number of papers have studied the residential segregation of migrants (e.g. Cutler et al., 1999, for the US; Boeri et al., 2012, for Italy). Interestingly for our purposes, these papers focused on medium-large size cities, implicitly signalling that segregation is clearly a phenomenon that can arise only above a certain population threshold. Second, people living in big cities are on average more skilled: the share of graduates in big cities (municipalities in the top 1\% percentile of the population distribution) is more than twice that of the rest the population distribution. At the same time, as we show in Section 7, skilled workers may be more protected from the increased labor market competition resulting from immigration. ${ }^{13}$ Third, immigration in big cities may have started sooner than in smaller municipalities: the share of immigrants was equal to almost $2 \%$ in 1991 in big cities (top percentile) while being $0.8 \%$ in the remaining percentiles. This might imply that having become accustomed to the presence of the immigrants for some time could have induced an adaptive response in the natives' attitudes, diminishing initial apprehensions.

[Table 4]

\subsection{Robustness checks}

We carry out two main robustness checks: 1) the use of more aggregate data to deal with spillover effects; 2) the change in the electoral rule in 2005.

\footnotetext{
12 The $99^{\text {th }}$ percentile amounts to 70,188 residents. Since we have 7927 municipalities, after the $99^{\text {th }}$ percentile there are around 79 municipalities, the big cities.

13 This explanation is consistent with Mayda (2006), which stresses that attitudes towards immigration depend greatly on education levels.
} 


\section{Spillover effects}

Our identification strategy might come in for criticism due to the fact that immigration flows in a single municipality could also affect the surrounding municipalities through the mobility decisions of agents (workers and firms). In the case of native flights (Betts and Fairlie, 2003, Card and Di Nardo, 2000, among others), the arrival of immigrants triggers an outflow of natives towards borderline cities. In such a case, our estimates could prove biased. On more technical grounds, when spillover effects materialize the stable unit treatment value assumption (SUTVA) would not hold. The SUTVA, which is a crucial assumption in order to identify a causal effect in the IV framework correctly, states that the treatment status of any given unit does not have to affect the potential outcomes of other units.

To take the issue of possible spillovers into account we test whether our results hold using more aggregate spatial units. In particular, we move from about 8,000 municipalities to about 650 local labor markets ('Sistemi locali del lavoro'), which are self-contained areas since they are defined with respect to daily commuting patterns. We then aggregate all the relevant variables at the local labor market level, and perform the same estimates as in equation (1), using as weights the log voters at the local labor market level.

As shown in Table 5, our results do not change much with respect to the analysis at the municipality level, suggesting that spillover effects across surrounding municipalities play a negligible role. In particular, in the IV specification with local labor market fixed effects, a $1 \%$ increase in the share of immigrants entails an increase in the votes for the centre-right coalition of $1.01 \%$, which is just slightly lower than the figure computed in Table 3 . These results are also consistent with the findings of Cattaneo et al. (2013), who find no evidence of an increased likelihood that European workers will leave employment or the region of residence when immigrants 'take their jobs'.

\section{[Table 5]}

\section{Change in the electoral rules}

The second robustness check takes into account the fact that in 2005 Italy experienced a change in the electoral rule at the national elections (legge n. 270 - 2005, also named legge Calderoli). The new rule was approved by the centre-right coalition, while the centre-left coalition and the other small parties vigorously opposed to it. In 2001 the electoral rule consisted in a mixed system (75\% of seats elected with the majoritarian system, $25 \%$ with the proportional system). The new electoral rule introduced the following changes: a winning bonus (the party/coalition with the highest number of votes could have an overwhelming majority in Parliament); a threshold $(4 \%)$ for the smaller political parties to have Parliamentary representation; abolition of the possibility to choose the candidate (voters were only allowed to choose the party/coalition). The change in the electoral rule provides us with the lucky opportunity to test whether the impact of immigration on electoral outcomes is specific to a given set of rules. For instance, the political economy literature suggests that some electoral mechanisms, for instance 
the adoption of a majority electoral system, might be more sensitive to the role of particular issues (such as the regulation of immigration in specific municipalities) vis-à-vis the general ones, i.e. a high-profile and credible government (Gagliarducci et al., 2011, Milesi-Ferretti et al., 2002).

In Table 6 we illustrate the results obtained by considering each election separately. Even though the rules for the 2006 (won by the centre-left) and 2008 (won by the centre-right) elections differed from those of 2001, the impact of immigration on the voting for the centreright coalition is quite similar. Note also that in the specifications of table 6 we cannot introduce municipality fixed effects, since there is no time variation in the data. To control for spatial unobserved heterogeneity we make use for each election year of two different spatial unobserved heterogeneities, i.e. regional (NUTS-2) and provincial (NUTS-3) fixed effects.

[Table 6]

6.4 Who gains and who loses out from immigrants inflows?

So far we have investigated the impact of immigration on the votes for the centre-right coalition, which is our main dependent variable. However, it is interesting to look into the impact of immigration on additional electoral outcomes.

First, we focus on the impact on the votes for other political coalitions. We compute the vote shares for the centre, the centre-left, and the extreme left coalitions. The centre-left is the most important, i.e. winner of the election in 2006, headed by Romano Prodi. We also disentangle the centre-right coalition between the extreme right component and the moderate right component. We then replicated our preferred specification, IV estimates with municipality fixed effects, for this full-fledged set of coalitions' electoral outcomes. Column (1) of Table 7 refers to votes for the extreme-right component, which were included in the centre-right coalition in previous estimates. Interestingly, we find that the coefficient is much smaller, i.e. 0.236, suggesting that in the case of Italy immigration has boosted the extreme right-wing party to a limited extent. Note however that the share of the extreme right party is much smaller than that of the moderate component, and hence in relative terms the impact is even greater, even if with little importance for the election outcome. When considering the moderate right component, the impact is still very strong (1.024), confirming that the impact of immigration on electoral outcomes in Italy came through the moderate voters. Furthermore, the higher share for centreright coalitions comes at the expense of votes for the Centre, the Centre-left and the extreme left, as expected. However, only for the Centre-left coalition, which competed closely with the centre-right to win the elections, the coefficient is statistically significant (-0.673).

[Table 7] 
Another series of outcomes worth investigating relates to the possibility that an increase of immigrants might have not only shifted votes across parties, but might also have affected the turnout at the elections and some forms of political protests, such as ballot papers deliberately left blank or made invalid. Also for these outcomes we illustrate the results from our preferred specification, the IV approach with municipality fixed effects. The results are set out in Table 8 . It emerges that the increase in immigration has a negative impact on voter turnout. Even if the coefficient is (only just) not statistically significant (t-stat equals to 1.56), it might suggest that left-wing voters, who are ideologically in favor of a multi-ethnic society but are not happy about the immigration trends and regulations, might have decided not to vote instead of directly voting for the centre-right coalition. A similar interpretation can be applied to the findings regarding blank and invalid ballots, which show a sharp increase with the share of immigrants, with coefficients higher than one and largely significant: some individuals are not satisfied with any of the existing political parties and the related immigration platforms, and prefer to signal their disappointment using this form of protest.

[Table 8]

\section{Possible channels behind our findings}

In this Section we investigate the transmission mechanism going from inflow of immigrants to the natives' voting behavior. We start to explore this issue from a descriptive point of view by making use of the Itanes microdata provided by the Istituto Cattaneo, a leading Italian research foundation dealing mainly with electoral studies. In particular, we use responses from more than 6,000 voters who were interviewed after the 2001 general election. These data are particularly suitable to our aims since they include information on both voting and attitudes towards immigrants, as well as the usual socio-demographic variables. Although Itanes data cannot be used for a rigorous causal analysis, 14 they offer interesting insights into the mechanism that underlies the relationship between immigration and the political preferences of natives.

The Itanes questionnaire identifies four main channels that might explain about why some natives think that immigration is a very important (and alarming) issue. The first channel refers to the cultural dimension, to the fact that immigration might represent a threat to Italian culture. Some papers underline the importance of issues such as cultural diversity (Ottaviano and Peri, 2006), compositional amenities (Card et al., 2012), and religion diversity (Barro and McCleary, 2003). The second channel concerns the competition of immigrants in the labor market. The literature has stressed that in a developed country the native-immigrant contest for jobs should be tougher for unskilled native workers (Borjas, 2003, Mayda, 2006). This insight is particularly relevant to the case of Italy, where immigrants are for mostly unskilled, and even the few medium or high skilled are usually employed in unskilled occupations and have

\footnotetext{
14 The sample is not representative for the whole country, since it over-represents medium-big cities; moreover, although the waves of the Itanes survey are available for general elections held in 2001, 2006 and 2008, the type and wording of questions change across waves.
} 
higher over-education rates (Dell'Aringa and Pagani, 2011). The third channel concerns competition for public services. Of course, it is children and the elderly who make most use of public services. Since immigration is a very recent phenomenon in Italy, the share of immigrant elderly individuals is negligible On the contrary, immigrants have a very high fertility rate, especially when compared to the very low rate for Italians. ${ }^{15}$ As matter of fact, the increase in immigration rates since the beginning of the nineties has determined a huge rise in the share of immigrant children in proportion to native children. This has generated strong competition between immigrants and natives for public services for children, especially admission to public schools. Moreover, when at school immigrants may negatively affect the performance of native children (Ballatore et al., 2013). The fourth channel refers to the perception by natives that immigration can lie behind increase in criminal activities. This is a standard claim in the political campaign, and it has been traditionally used by the centre-right coalition. Note that what matters is not whether immigration actually has a causal impact on crime. In this regard, the paper by Bianchi et al (2012) suggests that, when controlling for endogeneity, immigration does not raise the crime rate in Italy. What really matters is the perception of natives, which can be affected by political campaigns.

Using the Itanes data, it is possible to compute the descriptive correlation between being worried about immigration and the above-mentioned channels. Controlling for age, gender, years of schooling, and occupational status, in the different columns of Table 9 we regress the dummy variable "immigration is a very important issue" on the following dummies: "immigrants are a threat to our culture"; "immigrants are a threat to our job"; individuals having children and "immigrants are a threat in terms of crime". All dummies are positively associated with the belief that immigration is an important issue. This evidence applies both when dummies are introduced in the regression one at a time (Column 1-4) and when introduced all at once (column (5)), with having children no longer being statistically significant but still positive).

[Table 9]

We move on to rigorous investigation into the validity of the four channels, by means of estimates with interaction terms. In particular, we split the whole sample of municipalities by using 1991 data, to make them as exogenous as possible with respect to migration trends in our analysis, referring to the period 2001-2008.16 In particular, for each channel we compute a proxy variable, and then compute a corresponding dummy variable (above or below the median). We introduce in the baseline regression the immigrant share and the interaction between immigrant share and the dummy variable for each channel. For the sake of brevity, we only show the results from our preferred specification, the IV with municipality fixed effects. As

\footnotetext{
${ }^{15}$ According to Istat, in 2009-2010 the average number of children amounted to 1.31 for Italian women and 2.23 for immigrant women.

16 To derive the thresholds we make use of Istat Census data for 1991.
} 
standard when using interaction term, the instrument for the interaction is equal to the standard instrument times the interaction dummy.

As for the first channel, the cultural dimension, we rank municipalities according to cultural diversity, based on a distance function that draws on religion data. Foner and Alba (2008), among others, shows that immigrant religion might facilitate the successful integration of immigrants and that religion-related activities encourage the development of integrative social identities. Of course, religion in Italy is a crucial cultural dimension, since Italy hosts the Vatican State and the Pope and is considered the centre of Catholicism. For each municipality we compute a religion diversity index which is given by the mean squared difference between the share of Catholics in Italy and that of the first fifteen outbound countries, using the shares of 1991 foreign resident nationalities in the municipality as weights. We then derive a dummy equal to one when a municipality is above the median of this religious diversity index. Column (1) in Table 10 shows that the baseline coefficient is significant and equal to 0.812 . Interestingly, the interaction term is highly significant statistically, coming to 0.433 , and suggesting that where religious/cultural diversity is greater the impact is stronger. ${ }^{17}$

As for the second channel, competition in the labor market, we compute a dummy variable equal to one if the share of graduates in a municipality is lower than the median of the graduate share computed on all municipalities. Also in this case the baseline coefficient is positive, significant and similar to the one in Table 3, while the interaction term is positive (0.580) and highly significant, implying that the impact of immigration is driven by the group of relatively 'unskilled' municipalities (column (2)). This evidence supports the idea that the switch of votes to the centre-right coalition driven by immigration has something to do with the rise in competition in the unskilled labor market.

For the third channel, competition for the public services, we split the sample according to the share of native children, i.e. native population in the class of age 0-14, computed in 1991. The intuition is that the higher is the share of native children, the higher may be the perception that immigrants can 'steal' admission to school in the place of natives. ${ }^{18}$ We then compute a dummy variable equal to one for municipalities above the median of the native children's share. Column (3) of Table 10 shows that the impact of immigration is driven by the group of municipalities above the median, since the interaction term is positive (0.718) and highly significant. This suggests that the perception that immigration can be a treat for benefiting from public services also plays a role.

The last channel is crime, i.e. the perception that immigration is a driver of crime. To deal with this issue, we identify the five nationalities associated with the highest rate of criminal activity, which are the following: Egyptian, Moroccan, Rumanian, Serbian, Tunisian. ${ }^{19}$ We then

\footnotetext{
${ }^{17}$ Note that the Cragg-Donald Wald F statistic of the first stage is greater than ten. The same applies to all the other columns (apart from column (5) where it comes to 7.3).

${ }^{18}$ Halla et al (2013) makes use of a similar sample split approach, using the share of immigrant children. We use native children's since we believe that immigrant children is endogenous.

19 These nationalities have been identified using the first available data on criminal activity by nationality, in 2008, provided by Istat. Using these data it is possible to compute the crime rate for each nationality, i.e. criminal acts by individuals belonging to that specific nationality out of the total number of immigrants of that nationality.
} 
compute the share of immigrants belonging to these five nationalities for all municipalities, using 1991 data. The idea is that the perception of a relation between immigration and crime is more accentuated in municipalities characterized by a large presence of immigrants of the nationalities with higher crime rates (computed at the national level). The dummy variable is equal to one for municipalities above the median of shares of immigrants of these nationalities. Column (4) of Table 10 suggests that also for this channel the point estimate of the interaction term is positive, i.e., the impact is higher in municipalities above the median. However, the interaction term and the baseline coefficient are not statistically significant, suggesting lower explanatory power for this channel.

In column (5) we introduce the interactions all at once, using as instruments all the interacted instruments. This check is important since one might argue that the channels are correlated across municipalities, and hence it is crucial to include them all at once in the regression. Interestingly, the baseline coefficient is positive and not statistically significant. This is not surprising since it refers to municipalities characterized at the same time by low cultural diversity, high education levels, low shares of native children and low incidence of nationalities associated with crime. When moving to interaction terms, the statistical significance remains the same as in column (1)-(4), and coefficients are only slightly lower than those in columns (1)(4), implying that channel correlation across municipalities is not a major issue. We can therefore conclude that the only channels that entail a significant impact on votes concern cultural diversity, competition in the labor market, and competition for public services.

[Table 10]

\section{Conclusions}

The paper analyzes the impact of immigration on the political preferences of natives. We focus on the case of Italy, which is particularly interesting because the country has experience fast and large migration inflows as well as right-wing rule for the last 15-20 years. We use municipality data that allow for controlling for unobserved municipality heterogeneity and endogeneity. We find that in municipalities that experienced relatively larger arrivals of immigrants, the electorate has been more willing to vote for the centre-right coalition with political platforms less favorable to the immigrants. The size of the city matters: big cities behave differently from the others, since no effect of immigration on electoral outcomes is detected. We also point out that the gain in votes for the centre-right coalition went hand in hands with a loss of votes for the centre-left parties (and the smaller parties, except those on the extreme right), with a decrease in voter turnout and an increase in protest votes. Our findings seem to be explained by multiple channels, which refer to cultural diversity, to the nativeimmigrants competition in the labor market and in access to public services, while the native perception that immigrants cause crime produces the expected impact but is not statistically significant. 
Our results regard a country that has recently experienced a surge in immigrant inflows. To the extent that the aversion to immigration decreases over time (because people feel less threatened or start to appreciate the benefits of immigration that might take time to materialize) the impact of immigration on political outcomes might diminish over time. 


\section{References}

Ballatore, R., Fort, M., Ichino, A. (2014), “Babel's tower in the classrom? Immigrants and natives in Italian schools", mimeo.

Barro, R., McCleary, R.M. (2003), "Religion and Economic Growth", NBER Working Paper no. 9682.

Betts, Julian R., and Fairlie, R.W. (2003), "Does immigration induce 'native flight'from public schools into private schools?.", Journal of Public Economics, 87.5: 987-1012.

Borjas George J. (2003) “The Labor Demand Curve is Downward Sloping: Reexamining the Impact of Immigration on the Labor Market", Quarterly Journal of Economics, 118 (4), 13351374.

Bianchi, M., Buonanno, P., Pinotti, P. (2012), "Do Immigrants Cause Crime?", Journal of the European Economic Association, Vol. 10(6), pp. 1318-1347.

Boeri, T., De Philippis, M., Patacchini, E., Pellizzari, M. (2012), "Moving to Segregation: Evidence from 8 Italian Cities", IZA Discussion Papers 6834, Institute for the Study of Labor (IZA).

Card, D. (2001), "Immigrant Inflows, Native Outflows, and the Local Market Impacts of Higher Immigration", Journal of Labor Economics, 19, 22-64

Card, David, and John E. Di Nardo (2000), "Do immigrant inflows lead to native outflows?", American Economic Review, 90.

Card, D., Dustmann, C., \& Preston, I. (2012), Immigration, wages, and compositional amenities. Journal of the European Economic Association, 10(1), 78-119.

Cattaneo, C., Fiorio C. and Peri G. (2013) "What Happens to the Careers of European Workers When Immigrants "Take Their Jobs"?", IZA Discussion paper, no. 7282.

Corbetta P. and Piretti M. S. (2009), Atlante storico-elettorale d'Italia, 1861-2008, Bologna: Zanichelli.

Cutler, D.M., Edward L. Glaeser, and Jacob L. Vigdor (1999), "The rise and decline of the American ghetto", The Journal of Political Economy, 107(3):455-506.

Dell'Aringa, C., L. Pagani (2011), "Labour Market Assimilation and Over-Education: The Case of Immigrant Workers in Italy", Economia Politica, 2, 2011.

Deaton, A. (2010), Instruments, randomization, and learning about development. Journal of Economic Literature 48 (2): 424-455.

Durante, R., and B. G. Knight (2012), Partisan Control, Media Bias, and Viewer Responses: Evidence from Berlusconi's Italy, Journal of the European Economic Association, 10, 451-481.

Eurostat (2013) Population by citizenship [http:/ / epp.eurostat.ec.europa.eu/tgm/table.do?tab=table\&init=1\&plugin=1\&language=en \&pcode $=$ tps00157]

Facchini, G., \& Mayda, A. M. (2009), "Does the welfare state affect individual attitudes toward immigrants? Evidence across countries". The review of economics and statistics, 91(2), 295-314.

Foner, N. and R. Alba (2008) "Immigrant religion in the U.S. and Western Europe: bridge or barrier to inclusion?", International Migration Review, 42 (2)

Friedberg, R. M., and J. Hunt (1995), "The Impact of Immigrants on Host Country Wages, Employment and Growth", Journal of Economic Perspectives, 9, 23-44.

Gagliarducci, S., T. Nannicini, and P. Naticchioni (2011), “Electoral rules and politicians' behavior: a micro test.", American Economic Journal: Economic Policy, 3.3: 144-174. 
Gerdes, C., and E. Wadensjö (2008) "The Impact of Immigration on Election Outcomes in Danish Municipalities," IZA Discussion Papers 3586

Ginsborg, P. (2005), Silvio Berlusconi - television, power and patrimony, Verso.

Halla, M., A. Wagner, and J. Zweimüller (2013), “Does Immigration into Their Neighborhoods Incline Voters Toward the Extreme Right? The Case of the Freedom Party of Austria," IZA Discussion Papers, 6575, 2012, updated version available at http://www.econ.jku.at/halla.

Istat (2011), Cittadini Stranieri. Bilancio demografico anno 2010 e popolazione residente al 31 dicembre.

Istat (2011), Popolazione residente al $1^{\circ}$ gennaio.

Istat (1991), Census of population and housing, 1991.

Istat (2001), Census of population and housing, 2001.

Itanes - Istituto Carlo Cattaneo, Surveys on voting behaviour in Italy (2001, 2006, 2008) [http://www.itanes.org/en/questionnaires/]

Lane, D. (2005), Berlusconi's Shadow: Crime, Justice and the Pursuit of Power, Penguin Books

Mendez, I., and I. M. Cutillas (2014), "Has immigration affected Spanish presidential elections results?", Journal of Population Economics, 27, 135-171.

Milesi-Ferretti, Gian Maria, Roberto Perotti, and Massimo Rostagno (2002), "Electoral Systems and Public Spending.", Quarterly Journal of Economics, 117(2): 609-57.

Moehling C., and A. M. Piehl (2007), "Immigration and Crime in Early 20th Century America," NBER Working Papers, 13576.

Ottaviano, G., and G. Peri (2006), "The economic value of cultural diversity: evidence from US cities," Journal of Economic Geography, 6, 9-44.

Ottaviano, G., and G. Peri (2008), "Immigration and National Wages: Clarifying the Theory and the Empirics", NBER Working Papers, 14188.

Otto, A. H., and M. F. Steinhardt (2014), Immigration and election outcomes - Evidence from city districts in Hamburg, Regional Science and Urban Economics, 45, 67-79.

Passarelli, G. (2013), "Extreme right parties in Western Europe: the case of the Italian Northern League", Journal of Modern Italian Studies, 18, 53-71.

United Nations (2013), “International Migration Report 2013”. 
Figures

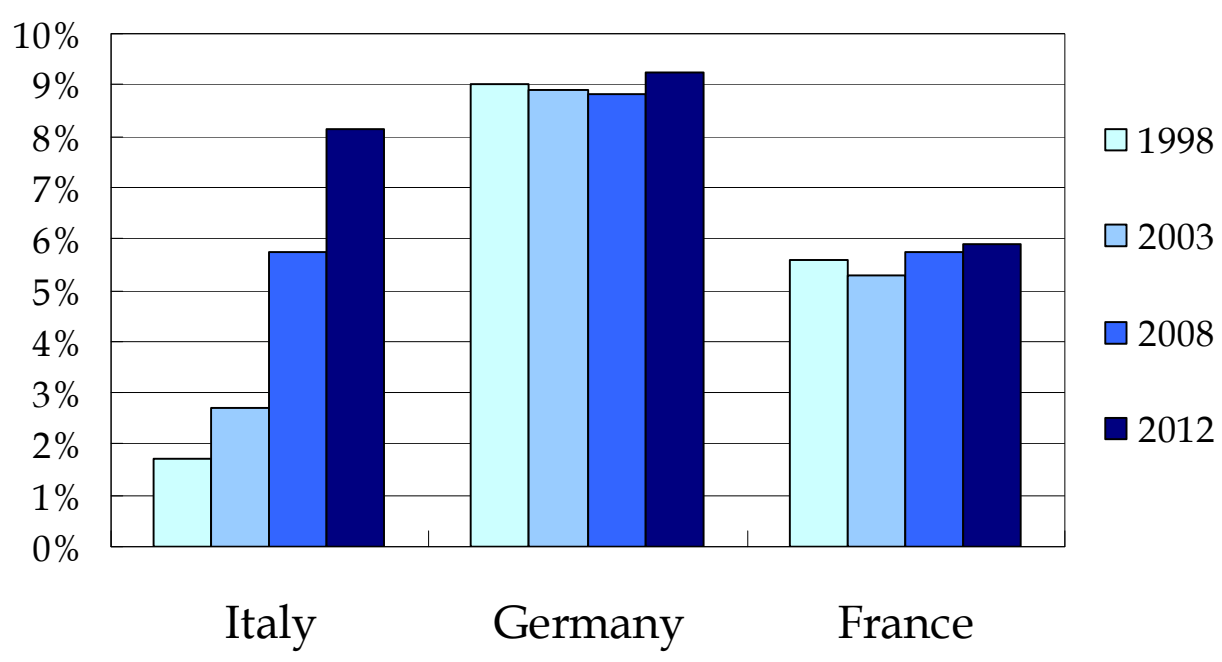

Figure 1: Resident Immigrant trends in Italy, Germany, France.

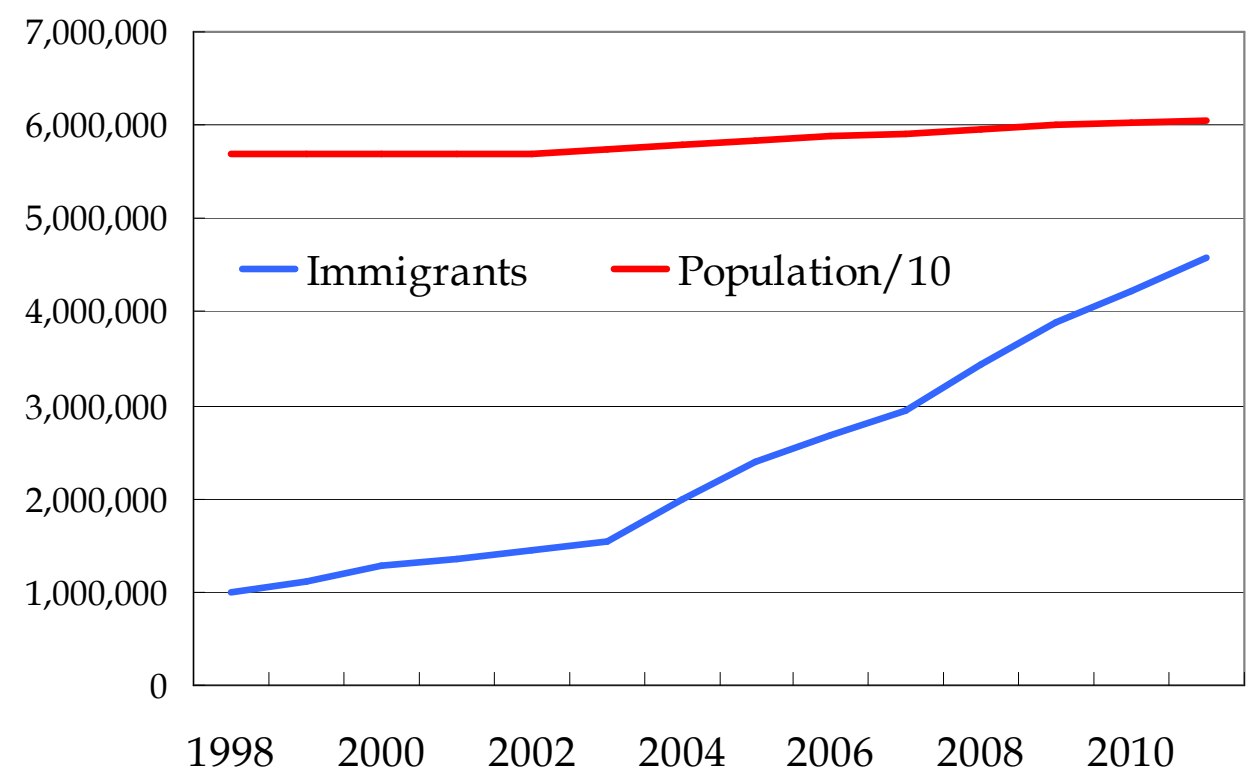

Figure 2: Immigration trends in Italy (residents), from 1998 to 2011. 




Figure 3: Electoral poster for the Centre-Right Coalition

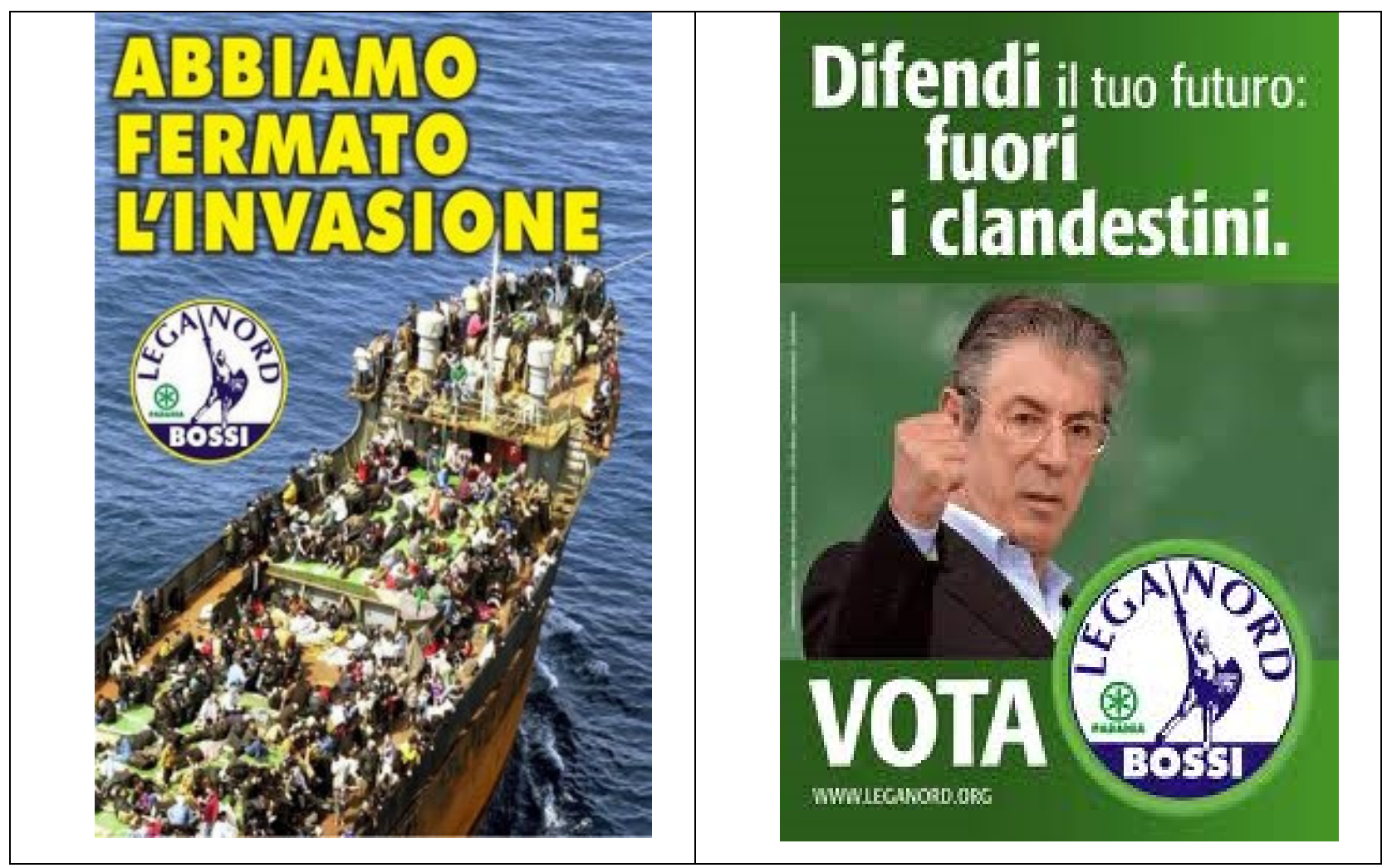

Figure 4: Electoral poster of the Lega Nord (Northern League), belonging to the centre-right coalition 


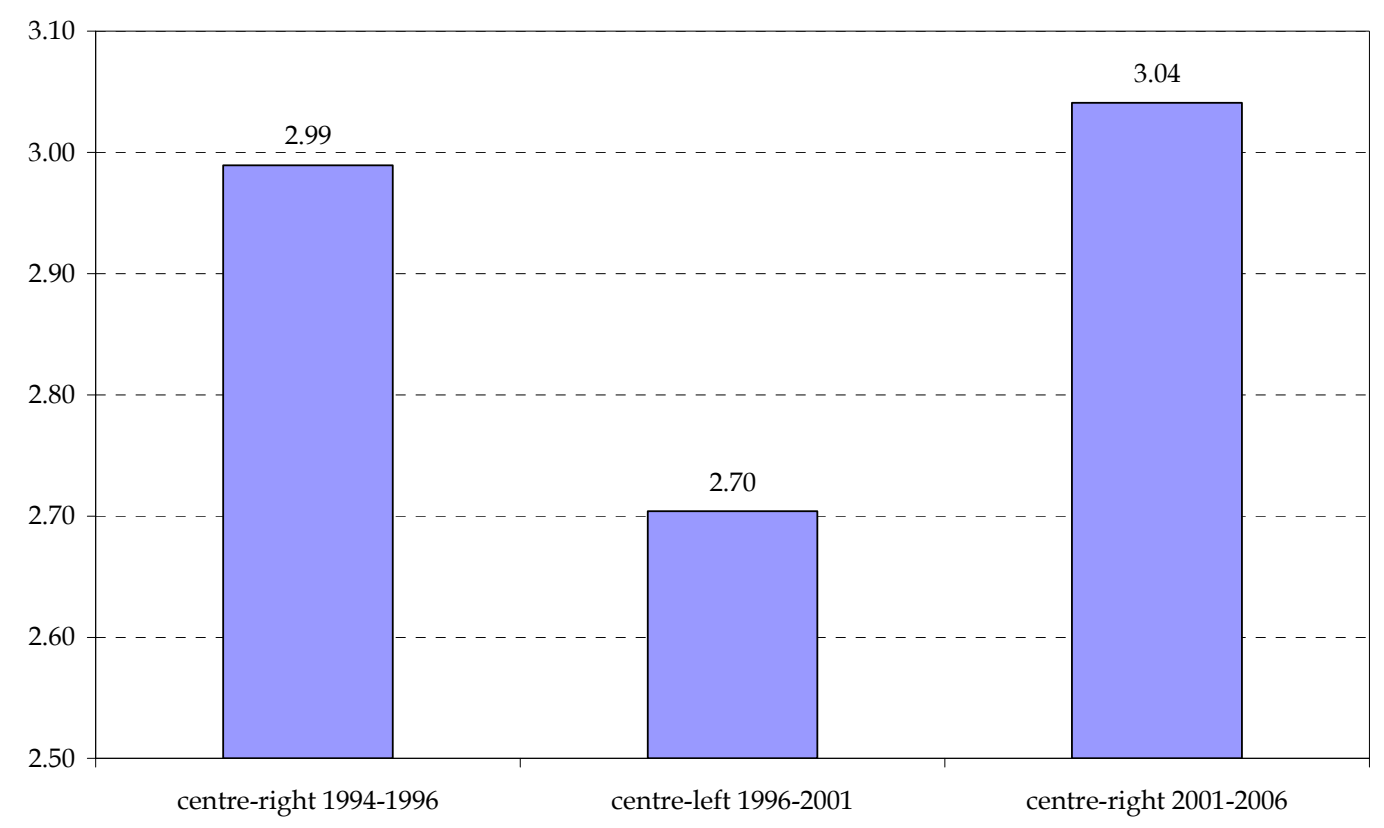

Figure 3. Strictness of anti-immigration policy in Italy, by type of ruling government. 


\section{Tables}

\begin{tabular}{|c|c|c|c|c|c|c|c|c|}
\hline Country & $\begin{array}{c}\# \\
\text { admission } \\
\text { req. }\end{array}$ & $\begin{array}{c}\# \\
\text { residence } \\
\text { req. }\end{array}$ & $\begin{array}{l}\text { \# years to } \\
\text { obtain } \\
\text { perm. } \\
\text { residence }\end{array}$ & $\begin{array}{l}\text { \# admin. } \\
\text { involved }\end{array}$ & $\begin{array}{l}\text { Length of } \\
\text { the first } \\
\text { stay }\end{array}$ & $\begin{array}{l}\text { Existence } \\
\text { of a quota } \\
\text { system }\end{array}$ & $\begin{array}{c}\text { Asylum } \\
\text { legislation }\end{array}$ & $\begin{array}{l}\text { OVERALL } \\
\text { INDEX }\end{array}$ \\
\hline Austria & 0 & 4.5 & 1 & 4 & 2 & 4 & 4 & 2.8 \\
\hline Denmark & 0 & 6 & 2 & 4 & 4 & 2 & 4.5 & 3.2 \\
\hline Finland & 4 & 3 & 1 & 2 & 4 & 2 & 3.5 & 2.8 \\
\hline France & 0 & 0 & 1 & 2 & 2 & 2 & 3.5 & 1.5 \\
\hline Germany & 0 & 6 & 1 & 2 & 2 & 2 & 5 & 2.6 \\
\hline Greece & 0 & 3 & 4 & 4 & 2 & 2 & 4 & 2.7 \\
\hline Ireland & 2 & 4.5 & 4 & 4 & 2 & 2 & 2 & 2.9 \\
\hline Italy & 4 & 4.5 & 2 & 2 & 2 & 4 & 3.5 & 3.1 \\
\hline Netherlands & 4 & 1.5 & 1 & 4 & 4 & 2 & 4.5 & 3 \\
\hline Portugal & 4 & 3 & 3 & 2 & 2 & 4 & 3.5 & 3.1 \\
\hline Spain & 6 & 1.5 & 1 & 4 & 2 & 4 & 4 & 3.2 \\
\hline UK & 2 & 1.5 & 4 & 4 & 2 & 2 & 4.9 & 2.9 \\
\hline
\end{tabular}

The Index for the strictness of migration policies "Fondazione Rodolfo De Benedetti" calculates an aggregate index which includes the following seven items: (i) the number of certificates and/or procedures needed to be admitted in a country; (ii) the number of certificates and/or procedures required to legally reside in the territory; (iii) the number of years needed to obtain a permanent residence permit; (iv) the number of administrations involved in the authorization procedures; $(\mathrm{v})$ the number of years of stay required to obtain a first residence permit; (vi) the existence of a quota system; (vii) the severity of the asylum legislation. For more information see: http://www.frdb.org/language/eng/topic/data-sources/doc_pk/11028 


\begin{tabular}{lcccc}
\hline Table 2. Descriptive statistics & & & & \\
\hline Time-variant Variables & Mean & Std. Dev. & Min & Max \\
\hline Centre-right coalition share & 0.49 & 0.13 & 0.00 & 0.89 \\
Share of immigrants & 0.04 & 0.04 & 0.00 & 0.29 \\
Population density & 0.29 & 0.63 & 0.00 & 13.09 \\
GDP growth rate & 0.00 & 0.02 & -0.04 & 0.04 \\
Population & 7350 & 40834 & 32 & 2724347 \\
\hline Time-invariant Variables & & & & \\
Social Capital & 0.02 & 0.04 & 0.00 & 0.94 \\
Aging index & 1.84 & 1.57 & 0.22 & 41.50 \\
Share of graduates & 0.04 & 0.02 & 0.00 & 0.37 \\
Employment rate & 0.37 & 0.08 & 0.13 & 0.61 \\
\hline
\end{tabular}

Centre-right coalition share comes from the Atlante Storico Zanichelli. Immigrant share is taken from Istat. The time variant covariate come from the Istat Territorial Statistics, while the time invariant covariates comes from the Istat Census in 2001.

\begin{tabular}{|c|c|c|c|}
\hline & (1) & (2) & (3) \\
\hline & OLS & $\overline{F E}$ & FE-IV \\
\hline \multirow[t]{2}{*}{ Immigrant share } & $0.389^{* * *}$ & $0.284^{* * *}$ & $1.260^{* *}$ \\
\hline & $(0.045)$ & $(0.033)$ & $(0.562)$ \\
\hline \multirow[t]{2}{*}{$\overline{\text { Density }}$} & $0.019^{* * *}$ & $0.094^{* * *}$ & 0.011 \\
\hline & $(0.003)$ & $(0.014)$ & $(0.050)$ \\
\hline \multirow[t]{2}{*}{ GDP growth NUTS-2 } & 0.034 & $0.669^{* * *}$ & $0.595^{* * *}$ \\
\hline & $(0.066)$ & $(0.035)$ & $(0.056)$ \\
\hline \multirow[t]{2}{*}{ Population/1000 } & $-0.000^{*}$ & $-0.000^{*}$ & -0.001 \\
\hline & $(0.000)$ & $(0.000)$ & $(0.001)$ \\
\hline \multirow[t]{2}{*}{ Social Capital } & 0.020 & & \\
\hline & $(0.027)$ & & \\
\hline \multirow[t]{2}{*}{ Aging index } & $-0.003^{* *}$ & & \\
\hline & $(0.001)$ & & \\
\hline \multirow[t]{2}{*}{ Share of graduates } & $-0.650^{* * *}$ & & \\
\hline & $(0.065)$ & & \\
\hline \multirow[t]{2}{*}{ Employment rate } & $0.220 * * *$ & & \\
\hline & $(0.021)$ & & \\
\hline \multirow[t]{2}{*}{ Constant } & $0.441^{* * *}$ & $0.459^{* * *}$ & \\
\hline & $(0.008)$ & $(0.004)$ & \\
\hline Observations & 23,774 & 23,780 & 23,780 \\
\hline Municipality FE & $\mathrm{NO}$ & YES & YES \\
\hline \multicolumn{2}{|l|}{ F-stat Excl.instruments } & & 27.20 \\
\hline$\overline{R \text {-squared }}$ & 0.153 & 0.528 & 0.490 \\
\hline \multicolumn{4}{|c|}{$\begin{array}{l}*, * *, * * * \text { stands for statistical significance at } 10,5 \text {, and } 1 \text { percent level, respectively. The } \\
\text { dependent variable is the share of votes for the centre-right coalition at the municipality } \\
\text { level. The immigrant share is computed over total municipality population. Standard } \\
\text { errors are clustered by municipality. Only for immigrant share standard errors are } \\
\text { included in parentheses. Instrument used in column in the IV estimates: share of } \\
\text { immigrants by municipality in } 1991 \text {. Observations are weighted by the log of individuals } \\
\text { having the right to vote at the municipality level. }\end{array}$} \\
\hline
\end{tabular}


Table 4 . The role of big cities. IV estimates. Population as weight.

\begin{tabular}{lcccccc}
\hline & \multicolumn{2}{c}{ All municipalities } & \multicolumn{2}{c}{ Up to 99th perc. } & \multicolumn{2}{c}{ Big cities } \\
\hline & $\mathbf{( 1 )}$ & $\mathbf{( 2 )}$ & $\mathbf{( 3 )}$ & $\mathbf{( 4 )}$ & $\mathbf{( 5 )}$ & $\mathbf{( 6 )}$ \\
\hline Immigrant share & FE & FE-IV & FE & FE-IV & FE & FE-IV \\
& $0.188^{* * *}$ & -0.272 & $0.302^{* * *}$ & $1.184^{*}$ & 0.074 & -0.259 \\
& $(0.052)$ & $(0.548)$ & $(0.049)$ & $(0.670)$ & $(0.175)$ & $(1.143)$ \\
\hline Density & 0.018 & 0.048 & $0.047^{* * *}$ & $0.042^{* * *}$ & 0.011 & 0.041 \\
& $(0.013)$ & $(0.036)$ & $(0.012)$ & $(0.014)$ & $(0.026)$ & $(0.095)$ \\
GDP growth NUTS-2 & $0.321^{* * *}$ & $0.392^{* * *}$ & $0.427^{* * *}$ & $0.277^{* *}$ & 0.071 & 0.112 \\
& $(0.084)$ & $(0.095)$ & $(0.046)$ & $(0.122)$ & $(0.229)$ & $(0.252)$ \\
Population/1000 & $-0.000^{* * *}$ & $-0.000^{* * *}$ & $-0.002^{* * *}$ & $-0.006^{*}$ & $-0.000^{* *}$ & $-0.000^{* *}$ \\
& $(0.000)$ & $(0.000)$ & $(0.001)$ & $(0.003)$ & $(0.000)$ & $(0.000)$ \\
Constant & $0.490^{* * *}$ & & $0.492^{* * *}$ & & $0.529^{* * *}$ & \\
& $(0.017)$ & & $(0.012)$ & & $(0.058)$ & \\
\hline Observations & 23,780 & 23,780 & 23,535 & 23,535 & 240 & 240 \\
\hline Municipality FE & YES & YES & YES & YES & YES & YES \\
\hline F-stat Excl.instruments & \multicolumn{7}{c}{23.17} & 10.68 & & 4.72 \\
\hline R-squared & 0.655 & 0.646 & 0.626 & 0.597 & 0.822 & 0.817 \\
\hline
\end{tabular}

$* * * * * * *$ stands for statistical significance at 10,5 , and 1 percent level, respectively. The dependent variable is the share of votes for the centre-right coalition at the municipality level. The immigrant share is computed over total municipality population. Standard errors are clustered by municipality. Only for immigrant share standard errors are included in parentheses. Instrument used in column in the IV estimates: share of immigrants by municipality in 1991. Observations are weighted by the individuals having the right to vote at the municipality level.

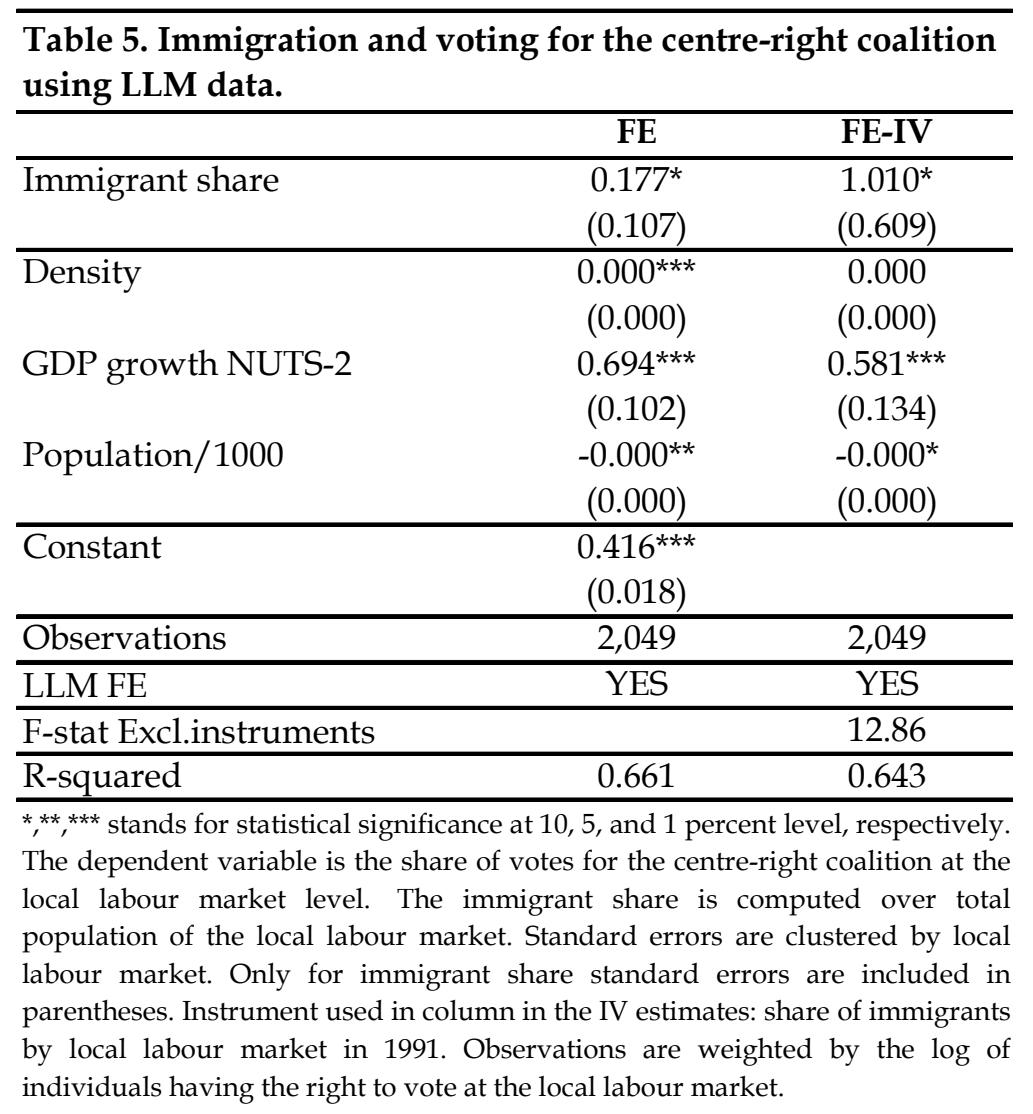


Table 6. Change in the electoral rule. Single election estimates. IV estimates.

\begin{tabular}{|c|c|c|c|c|c|c|}
\hline & \multicolumn{2}{|c|}{2001} & \multicolumn{2}{|c|}{2006} & \multicolumn{2}{|c|}{2008} \\
\hline & $\begin{array}{l}\text { Regional } \\
\text { FE }\end{array}$ & $\begin{array}{c}\text { Provincial } \\
\text { FE }\end{array}$ & $\begin{array}{c}\text { Regional } \\
\text { FE }\end{array}$ & $\begin{array}{c}\text { Provincial } \\
\text { FE }\end{array}$ & $\begin{array}{c}\text { Regional } \\
\text { FE }\end{array}$ & $\begin{array}{c}\text { Provincial } \\
\text { FE }\end{array}$ \\
\hline \multirow[t]{2}{*}{ Immigrant share } & $0.821^{\star * *}$ & $0.617^{* *}$ & $0.631^{* *}$ & $0.654^{* *}$ & $0.941^{* * *}$ & $0.893^{* *}$ \\
\hline & $(0.279)$ & $(0.258)$ & $(0.246)$ & $(0.256)$ & $(0.325)$ & $(0.348)$ \\
\hline \multirow[t]{2}{*}{ Density } & 0.002 & $-0.010^{* * *}$ & -0.002 & $-0.009^{* * *}$ & 0.000 & $-0.008^{* * *}$ \\
\hline & $(0.002)$ & $(0.002)$ & $(0.002)$ & $(0.002)$ & $(0.002)$ & $(0.002)$ \\
\hline \multirow[t]{2}{*}{ GDP growth NUTS-2 } & $-4.224^{* * *}$ & -1.549 & $-21.827^{* * *}$ & $-4.128^{* * *}$ & $-3.421^{* * *}$ & 0.579 \\
\hline & $(0.504)$ & $(2.654)$ & (1.819) & $(1.494)$ & $(0.304)$ & $(2.711)$ \\
\hline \multirow[t]{2}{*}{ Population/1000 } & $-0.000^{*}$ & 0.000 & -0.000 & 0.000 & -0.000 & 0.000 \\
\hline & $(0.000)$ & $(0.000)$ & $(0.000)$ & $(0.000)$ & $(0.000)$ & $(0.000)$ \\
\hline \multirow[t]{2}{*}{ Social Capital } & -0.018 & $-0.037^{*}$ & -0.023 & $-0.041^{* *}$ & -0.025 & $-0.045^{\star *}$ \\
\hline & $(0.026)$ & $(0.022)$ & $(0.022)$ & $(0.020)$ & $(0.025)$ & $(0.022)$ \\
\hline \multirow[t]{2}{*}{ Aging index } & $-0.005^{* * *}$ & $-0.002^{*}$ & $-0.005^{* * *}$ & $-0.004^{* * *}$ & $-0.008^{* * *}$ & $-0.006^{* * *}$ \\
\hline & $(0.001)$ & $(0.001)$ & $(0.001)$ & $(0.001)$ & $(0.002)$ & $(0.002)$ \\
\hline \multirow{2}{*}{ Share of graduates } & $-0.270 * * *$ & $-0.179 * * *$ & $-0.254^{* * *}$ & $-0.186^{* * *}$ & $-0.597 * * *$ & $-0.508^{* * *}$ \\
\hline & $(0.057)$ & $(0.053)$ & $(0.054)$ & $(0.054)$ & $(0.066)$ & $(0.067)$ \\
\hline \multirow[t]{2}{*}{ Employment rate } & $-0.272^{* * *}$ & $0.079 * *$ & $-0.099 * *$ & $0.122^{* * *}$ & $-0.178^{* * *}$ & 0.062 \\
\hline & $(0.040)$ & $(0.036)$ & $(0.042)$ & $(0.040)$ & $(0.054)$ & $(0.052)$ \\
\hline \multirow[t]{2}{*}{ Constant } & $0.682^{* * *}$ & $0.540 * * *$ & $0.863^{* * *}$ & $0.360 * * *$ & $0.499^{* * *}$ & $0.460 * * *$ \\
\hline & $(0.019)$ & $(0.089)$ & $(0.042)$ & $(0.016)$ & $(0.017)$ & $(0.073)$ \\
\hline Observations & 7,925 & 7,925 & 7,925 & 7,925 & 7,924 & 7,924 \\
\hline Regional FE & YES & $\mathrm{NO}$ & YES & $\mathrm{NO}$ & YES & $\mathrm{NO}$ \\
\hline Provincial FE & $\mathrm{NO}$ & YES & $\mathrm{NO}$ & YES & $\mathrm{NO}$ & YES \\
\hline F-stat Excl.instr. & 4.51 & 4.44 & 7.67 & 7.39 & 14.61 & 14.15 \\
\hline R-squared & 0.323 & 0.577 & 0.412 & 0.584 & 0.398 & 0.563 \\
\hline \multicolumn{7}{|c|}{$\begin{array}{l}\text { *,**,*** stands for statistical significance at } 10,5 \text {, and } 1 \text { percent level, respectively. The dependent variable is the share of } \\
\text { votes for the centre-right coalition at the municipality level. The immigrant share is computed over total municipality } \\
\text { population. Standard errors are clustered by municipality. Only for immigrant share standard errors are included in } \\
\text { parentheses. Instrument used in column in the IV estimates: share of immigrants by municipality in } 1991 \text {. In columns } \\
\text { (1), (3), (5) regional fixed effects (20) are introduced, while in columns (2), (4), (6) includes provincial fixed effects (103). } \\
\text { Observations are weighted by the log of individuals having the right to vote at the municipality level. }\end{array}$} \\
\hline
\end{tabular}




\begin{tabular}{|c|c|c|c|c|c|}
\hline & (1) & (2) & (3) & (4) & (5) \\
\hline & $\begin{array}{c}\text { Extreme } \\
\text { Right }\end{array}$ & $\begin{array}{c}\text { Moderate- } \\
\text { right }\end{array}$ & Centre & Centre-left & Left \\
\hline \multirow[t]{2}{*}{ Immigrant share } & $0.236^{* *}$ & $1.024^{*}$ & -0.689 & $-0.673^{*}$ & -0.158 \\
\hline & $(0.098)$ & -0.584 & $(0.499)$ & $(0.378)$ & $(0.168)$ \\
\hline \multirow[t]{2}{*}{ Density } & $-0.022^{* *}$ & 0.032 & 0.042 & -0.034 & -0.002 \\
\hline & $(0.009)$ & $(0.053)$ & $(0.045)$ & $(0.034)$ & $(0.015)$ \\
\hline \multirow[t]{2}{*}{ GDP growth NUTS-2 } & $-0.057^{* * *}$ & $0.652^{* * *}$ & $0.187^{* * *}$ & $-0.442^{* * *}$ & $-0.099 * * *$ \\
\hline & $(0.014)$ & $(0.057)$ & $(0.050)$ & $(0.042)$ & $(0.019)$ \\
\hline \multirow[t]{2}{*}{ Population/1000 } & 0.000 & -0.001 & 0.001 & 0.000 & 0.000 \\
\hline & $(0.000)$ & $(0.001)$ & $(0.000)$ & $(0.000)$ & $(0.000)$ \\
\hline Observations & 23,780 & 23,780 & 23,780 & 23,780 & 23,780 \\
\hline Municipality FE & YES & YES & YES & YES & YES \\
\hline F-stat Excl.instruments & 27.2 & 27.2 & 27.2 & 27.2 & 27.2 \\
\hline R-squared & 0.384 & 0.484 & 0.109 & 0.313 & 0.593 \\
\hline \multicolumn{6}{|c|}{$\begin{array}{l}* * *, * * * \text { stands for statistical significance at } 10,5 \text {, and } 1 \text { percent level, respectively. The dependent variable is } \\
\text { the share of votes for different parties at the municipality level (see column title). The immigrant share is } \\
\text { computed over total municipality population. Standard errors are clustered by municipality. Only for } \\
\text { immigrant share standard errors are included in parentheses. Instrument used in column in the IV } \\
\text { estimates: share of immigrants by municipality in } 1991 \text {. Observations are weighted by the log of } \\
\text { individuals having the right to vote at the municipality level. }\end{array}$} \\
\hline
\end{tabular}

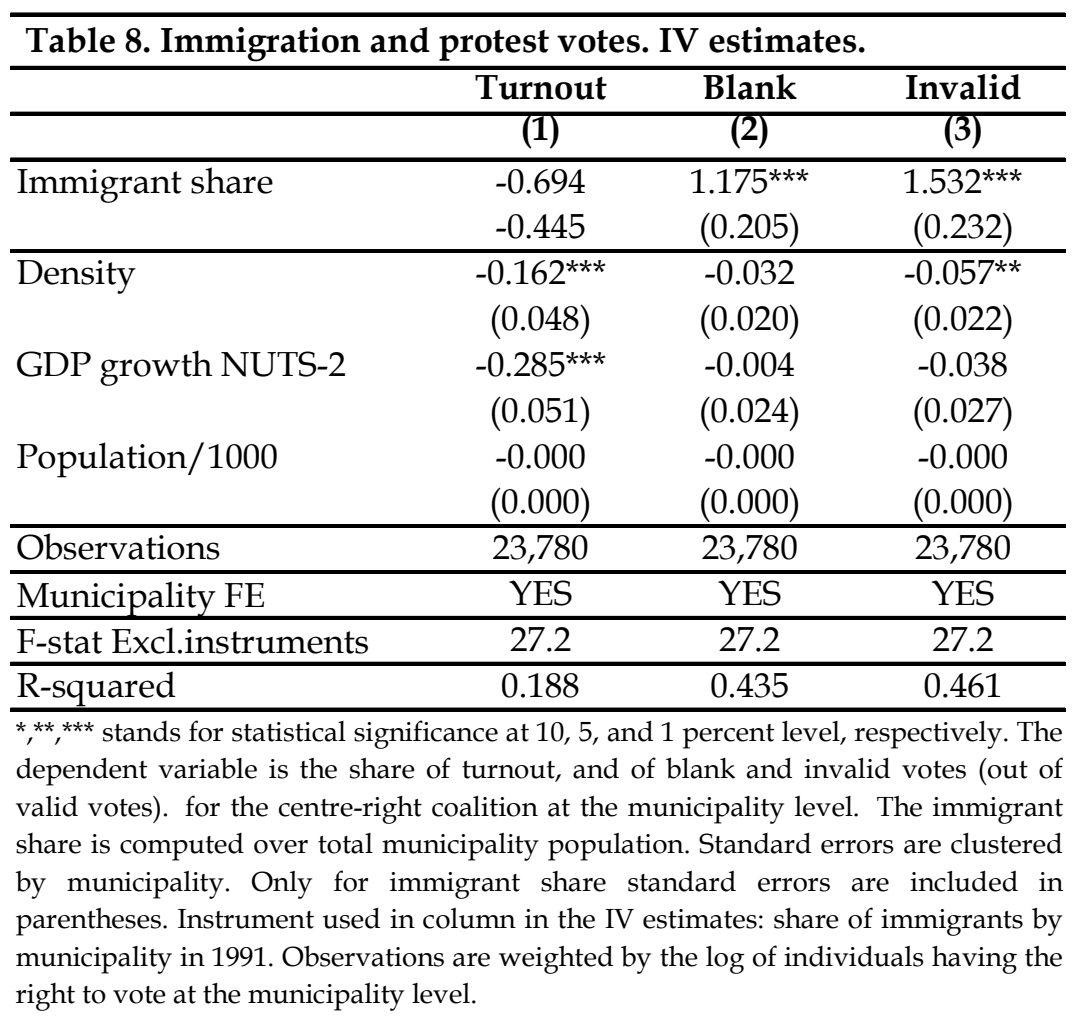


Table 9. Channels behind the relation between immigration and voting for the centreright. A descriptive exploration.

\begin{tabular}{|c|c|c|c|c|c|}
\hline & (1) & (2) & (3) & (4) & (5) \\
\hline Threat to Culture & $\begin{array}{l}0.162^{* * *} \\
(0.0173)\end{array}$ & & & & $\begin{array}{c}0.0605^{* * *} \\
(0.0212)\end{array}$ \\
\hline Threat to Jobs & & $\begin{array}{l}0.155^{* * *} \\
(0.0173)\end{array}$ & & & $\begin{array}{c}0.0639 * * * \\
(0.0210)\end{array}$ \\
\hline Having Children & & & $\begin{array}{l}0.0559 * * \\
(0.0221)\end{array}$ & & $\begin{array}{c}0.0295 \\
(0.0221)\end{array}$ \\
\hline Threat in terms of Crime & & & & $\begin{array}{l}0.198^{* * *} \\
(0.0180)\end{array}$ & $\begin{array}{l}0.146^{* * *} \\
(0.0216)\end{array}$ \\
\hline Controls & YES & YES & YES & YES & YES \\
\hline Observations & 3,115 & 3,131 & 3,099 & 3,187 & 3,038 \\
\hline
\end{tabular}

Table 10. Channels. Interaction models with respect to religious diversity, competition in the labour market (education), competition for public services (number of children), and intensity of crime. IV estimates.

\begin{tabular}{|c|c|c|c|c|c|}
\hline & (1) & (2) & (3) & $(4)$ & (5) \\
\hline Immigrant share & $\begin{array}{c}0.812^{*} \\
(0.447)\end{array}$ & $\begin{array}{l}1.234^{* *} \\
(0.545)\end{array}$ & $\begin{array}{l}0.961^{* *} \\
(0.444)\end{array}$ & $\begin{array}{c}0.731 \\
(0.816) \\
\end{array}$ & $\begin{array}{c}0.521 \\
(0.764) \\
\end{array}$ \\
\hline \multicolumn{6}{|l|}{ Interactions: } \\
\hline Imm. Share*High Cultural Diversity & $\begin{array}{c}0.433^{* * *} \\
(0.138)\end{array}$ & & & & $\begin{array}{c}0.345^{* * *} \\
(0.132)\end{array}$ \\
\hline Imm. Share*Low education level & & $\begin{array}{c}0.580^{* * *} \\
(0.233)\end{array}$ & & & $\begin{array}{l}0.362^{*} \\
(0.196)\end{array}$ \\
\hline Imm. Share*High share of Children & & & $\begin{array}{c}0.718^{* * *} \\
(0.264)\end{array}$ & & $\begin{array}{l}0.601^{* *} \\
(0.279)\end{array}$ \\
\hline Imm. Share ${ }^{*}$ High crime & & & & $\begin{array}{c}0.244 \\
(0.213)\end{array}$ & $\begin{array}{c}0.054 \\
(0.256)\end{array}$ \\
\hline Density & $\begin{array}{c}0.021 \\
(0.046)\end{array}$ & $\begin{array}{c}-0.008 \\
(0.055)\end{array}$ & $\begin{array}{l}-0.029 \\
(0.061)\end{array}$ & $\begin{array}{c}0.031 \\
(0.056)\end{array}$ & $\begin{array}{l}-0.021 \\
(0.076)\end{array}$ \\
\hline GDP growth & $\begin{array}{c}0.593^{* * *} \\
(0.055)\end{array}$ & $\begin{array}{c}0.572^{* * *} \\
(0.062)\end{array}$ & $\begin{array}{c}0.619^{* * *} \\
(0.050)\end{array}$ & $\begin{array}{c}0.614^{\star * *} \\
(0.061)\end{array}$ & $\begin{array}{c}0.603^{* * *} \\
(0.063)\end{array}$ \\
\hline Pop./1000 & $\begin{array}{l}-0.001 \\
(0.000) \\
\end{array}$ & $\begin{array}{l}-0.001 \\
(0.000) \\
\end{array}$ & $\begin{array}{l}-0.001 \\
(0.000) \\
\end{array}$ & $\begin{array}{l}-0.001 \\
(0.000) \\
\end{array}$ & $\begin{array}{l}-0.000 \\
(0.000) \\
\end{array}$ \\
\hline Observations & 23,780 & 23,780 & 23,780 & 23,780 & 23,780 \\
\hline Municipality FE & YES & YES & YES & YES & YES \\
\hline F-stat Excl.instruments & 17.473 & 10.977 & 14.136 & 10.595 & 7.329 \\
\hline R-squared & 0.491 & 0.466 & 0.487 & 0.512 & 0.490 \\
\hline
\end{tabular}

